\title{
THE ASSOCIATION OF ZN-CHROMITE WITH DIAMONDIFEROUS LAMPROPHYRES AND DIAMONDS: UNIQUE COMPOSITIONS AS A GUIDE TO THE DIAMOND POTENTIAL OF NON-TRADITIONAL DIAMOND HOST ROCKS
}

\author{
John Armstrong ${ }^{1}$ and Robert Barnett ${ }^{2} * *$ \\ ${ }^{l}$ C.S. Lord Northern Geoscience Centre, Yellowknife, Canada; ${ }^{2}$ RL Barnett Geological Consulting Inc., London,Canada
}

\section{INTRODUCTION}

Archean amphibole/phlogopite-bearing lamprophyre dykes, locally xenolith-bearing, transect rocks of the Yellowknife Supergroup at Yellowknife, Canada. Dykes and volcanic breccias with lamprophyric affinities occur in the Wawa area of the Michipicoten Greenstone belt in north central Ontario and share similarities to the Yellowknife lamprophyres. Most significant is that some Wawa lamprophyres are known to be diamond bearing and a small outcrop sample of the Jackfish lamprophyre at Yellowknife returned 2 clear yellow microdiamonds.

\section{Lamprophyre Zn-Chromites}

Yellowknife and Wawa lamprophyres have similar amphibole and mica compositions, typical of minettes Amphibole from the Yellowknife and Wawa lamprophyres are typically zoned from Mg-hastingsite / pargasite cores to actinolite-tremolite rims (Figure 1).

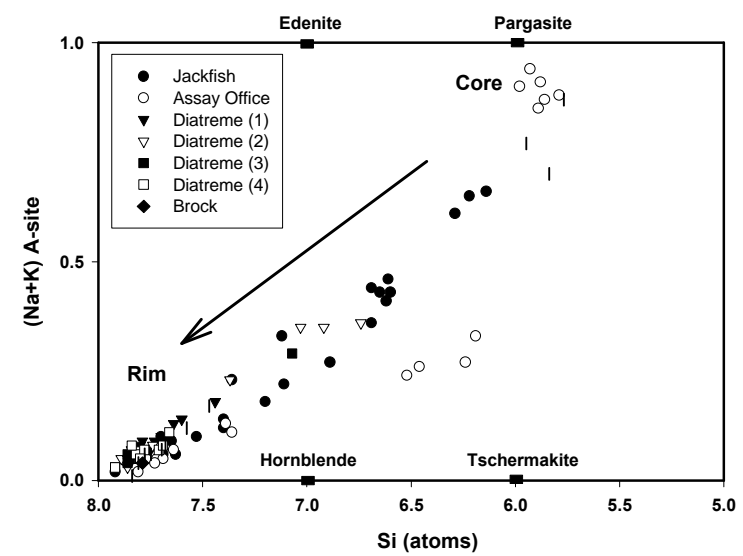

Figure 1. Compositional variation of lamprophyre amphibole in apfu. For Yellowknife lamprophyres, similar trends are observed in Wawa lamprophyres.

Micas from both locations are phlogopite-biotite ${ }_{\mathrm{ss}}$ with compositions typical of minettes (Figure 2) with elevated $\mathrm{Cr}_{2} \mathrm{O}_{3}$ and locally elevated $\mathrm{BaO}$ (to $2 \mathrm{wt} \%$ ).
Groundmass spinels in the Yellowknife lamprophyres demonstrate core-rim zonation with zinc-rich cores (to

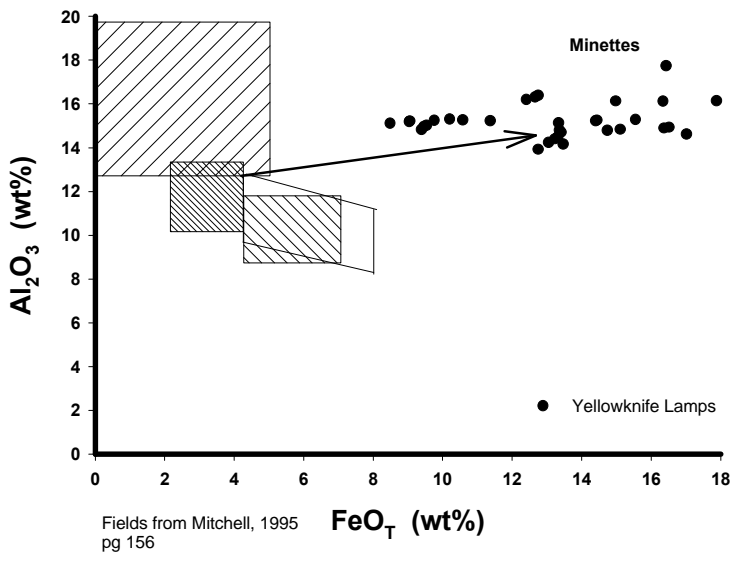

Figure 2. Compositional variation of phlogopite/biotite ${ }_{\mathrm{ss}}$, Yellowknife lamprophyres.

$7 \mathrm{wt} \% \mathrm{ZnO}$ ) and Cr-magnetite rims. Anhedral groundmass spinels are also $\mathrm{Zn}$-rich to $3 \mathrm{wt} \% \mathrm{ZnO}$ and display evolutionary trends toward $\mathrm{Cr}$-magnetite. In addition to the enriched $\mathrm{Zn}$ contents, the chromites are characterized by very low $\mathrm{MgO}(<0.5 \mathrm{wt} \%)$, elevated $\mathrm{MnO}(1.5-2.1 \mathrm{wt} \%)$, low $\mathrm{Al}_{2} \mathrm{O}_{3}(<10 \mathrm{wt} \%)$, low $\mathrm{TiO} 2$ ( $<1 \mathrm{wt} \%)$, and variable $\mathrm{Cr}_{2} \mathrm{O}_{3}$ (31 to $52 \mathrm{wt} \%$ ). Grains display a core-rim evolution of increasing $\mathrm{Cr}, \mathrm{Fe}^{3+}$ with decreasing Al, Zn. Significantly, the diamondiferous Wawa lamprophyres also contain groundmass spinels with elevated $\mathrm{ZnO}$ (to $>4 \mathrm{wt} \%$ ), $\mathrm{MnO}$ (to $>1.5 \mathrm{wt} \%$ ), low $\mathrm{MgO}$, low $\mathrm{Al}_{2} \mathrm{O}_{3}$, and moderate $\mathrm{Cr}_{2} \mathrm{O}_{3}$. Locally $\mathrm{Zn}$-chromite cores are overgrown by $\mathrm{Ti}-\mathrm{Cr}$-magnetite rims and $\mathrm{Mg}$-rich spinels $(\mathrm{MgO}$ to $>7 \mathrm{wt} \%$ have been noted) and vice versa. In their systematic core to marginal zonation with $\mathrm{Ti}-\mathrm{Cr}$-magnetite rims the lamprophyric Zn-rich chromites demonstrate evolutionary trends akin to magmatic spinels commonly found in kimberlite. Representaive analyses are listed in Table 1

Zn-chromites and Zn-spinels may also occur as accessory minerals within other ultramafic rocks and paleoplacer environments. Some of these $\mathrm{Zn}$-chromites 
display similarities to those from lamprophyres, while others contain elevated $\mathrm{Al} 2 \mathrm{O} 3$ contents, trending toward gahnite, indicative of metamorphic reactions

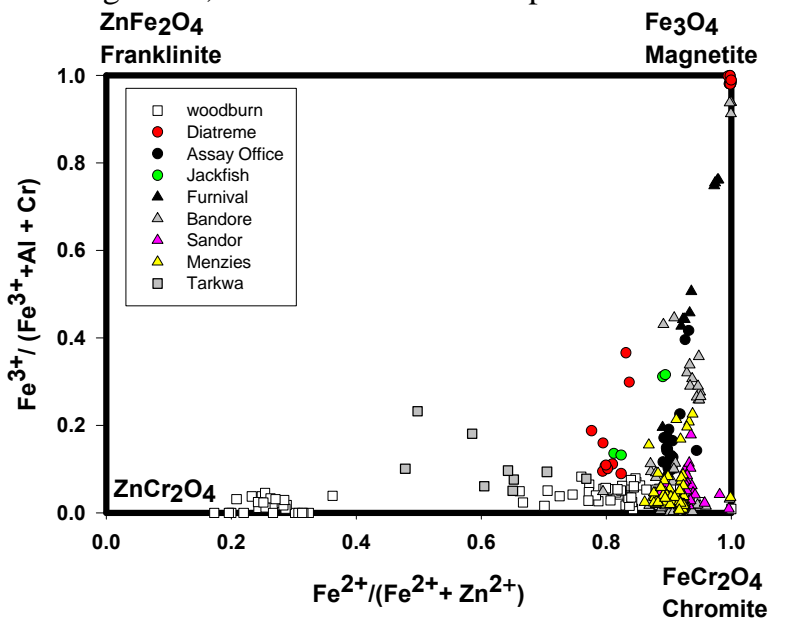

Figure 3. Planes within a modified spinel prism demonstrating magmatic reactions for $\mathrm{Zn}$-spinels from Wawa (Menzies, Sandor, Furnival, Bandore ) and Yellowkinfe (Diatreme, Jackfish, Assay Office). Zn-chromites from Archean- Paleoproterozoic paleoplacer environments display both metamorphic and magmatic trends (Woodburn, Tarkwa). Wawa data from Sage, 2000 and this study, Tarkwa data from Weiser and Hirdles (1997); Woodburn data from this study.

\section{Table 1 Representative Zn-chromite Analyses}

$\begin{array}{lllll} & 1 & 2 & 3 & 4 \\ \mathrm{SiO} 2 & 0.28 & 0.15 & \mathrm{na} & 0.29 \\ \mathrm{TiO} 2 & 0.21 & 0.49 & \mathrm{nd} & 0.09 \\ \mathrm{Al} 2 \mathrm{O} 3 & 4.70 & 9.37 & 2.70 & 3.23 \\ \mathrm{Cr} 2 \mathrm{O} 3 & 60.57 & 48.16 & 60.54 & 61.10 \\ \mathrm{Fe} 2 \mathrm{O} 3 & 1.31 & 7.76 & 3.58 & 2.68 \\ \mathrm{FeO} & 27.57 & 25.30 & 21.98 & 28.8 \\ \mathrm{MnO} & 1.69 & 1.43 & 1.41 & 0.41 \\ \mathrm{MgO} & 0.38 & 0.34 & \mathrm{nd} & 0.54 \\ \mathrm{NiO} & 0.3 & 0.00 & \mathrm{na} & \mathrm{na} \\ \mathrm{ZnO} & 3.31 & 7.23 & 9.78 & 2.38 \\ \mathrm{Total} & 100.05 & 100.23 & 99.99 & 99.78\end{array}$

1) Wawa-Bandore, 2) Yellowknife Diatreme,

3)Tarkwa(from Weiser and Hirdes, 1997), 4) inclusion in diamond from Meyer and Boyd (1972)

\section{Zn-Chromites in diamond}

Chromites with elevated zinc have been documented as inclusions in diamonds from Sierra Leone (Meyer and Boyd, 1972) and Brazil (Tappert et al., 2002) and are typified by low to moderate $\mathrm{MgO}$, low $\mathrm{Al}_{2} \mathrm{O}_{3}$, elevated $\mathrm{ZnO}$ approaching $7 \mathrm{wt} \%$, moderate to high $\mathrm{Cr}_{2} \mathrm{O}_{3}$ and moderate to low total Fe. Tappert et al (2002) implicate epigentic processes for $\mathrm{Zn}$ enrichment

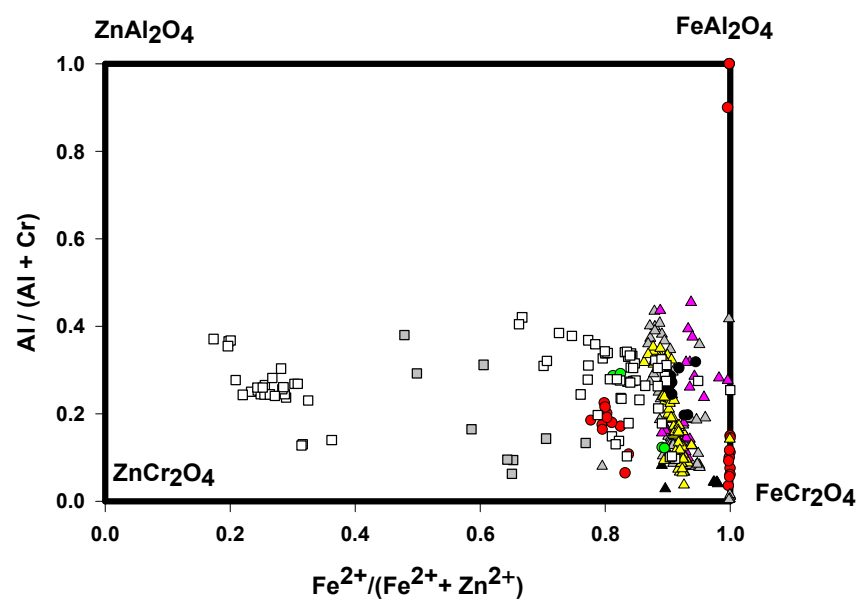

\section{DISCUSSION}

Collectively, the diamond-affinity Zn-spinel compositions differ from crustally derived or other magmatic spinels in their elevated zinc and consistently low contents of $\mathrm{MgO}$. As such, traditional plots utilized to relate chromites to diamond intergrowth and inclusion compositions are not applicable to $\mathrm{Zn}$-rich chromite compositions.

Given the rather unique nature of the $\mathrm{Zn}$-chromite compositions, a discriminant plot in ternary compositional space has been generated in terms of $\mathrm{Fe} 3 /(\mathrm{Fe} 3+\mathrm{Al})-\mathrm{Fe} 3 /(\mathrm{Fe} 3+\mathrm{Cr})-\mathrm{Al} /(\mathrm{Al}+\mathrm{Cr}$ ) (Figure 4).

Modification of this ternary, incorporating $\mathrm{Zn}$, allows

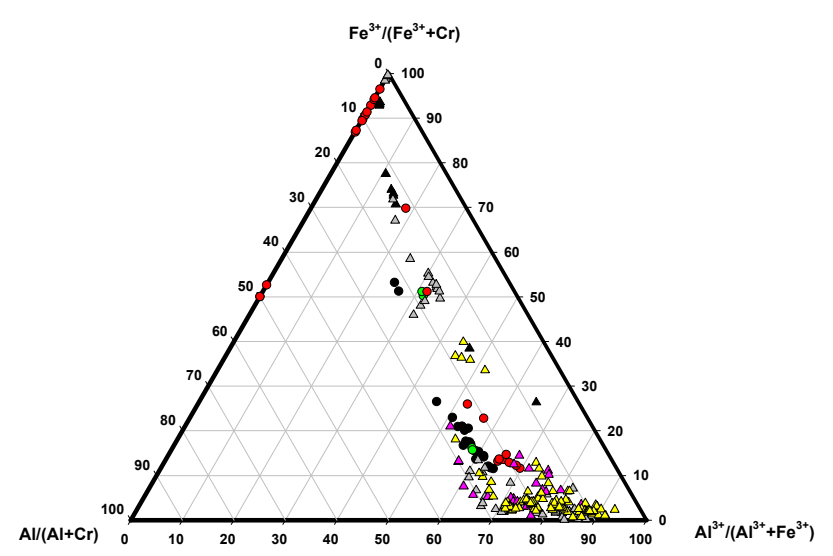

Figure 4. Ternary space for $\mathrm{Zn}$-spinels, symbols same as Figure 2.

discrimination between $\mathrm{Zn}$-chromite from diamondbearing lamprophyres from those of non-diamond 
bearing rocks (of crustal or magmatic derivation)(Figure 5). Significantly, the rare $\mathrm{Zn}$ chromites included within diamond also fall within the 'diamond-affinity Zn-spinel compositional space' defined for diamondiferous lamprophyres. Some analyses of $\mathrm{Zn}$-chromite grains from Paleoproterozoic paleoplacer environments may overlap with the diamond affinity compositional space. The ultimate source of these chromites is unknown and as such their origin may be indicative of older unrecognised diamond bearing rocks (ie. sourced in ultramafics or lamprophyric rocks).

Figure 5. Modified ternary space incorporating Zn content. Note that $\mathrm{Zn}$-chromites from diamond bearing rocks cluster

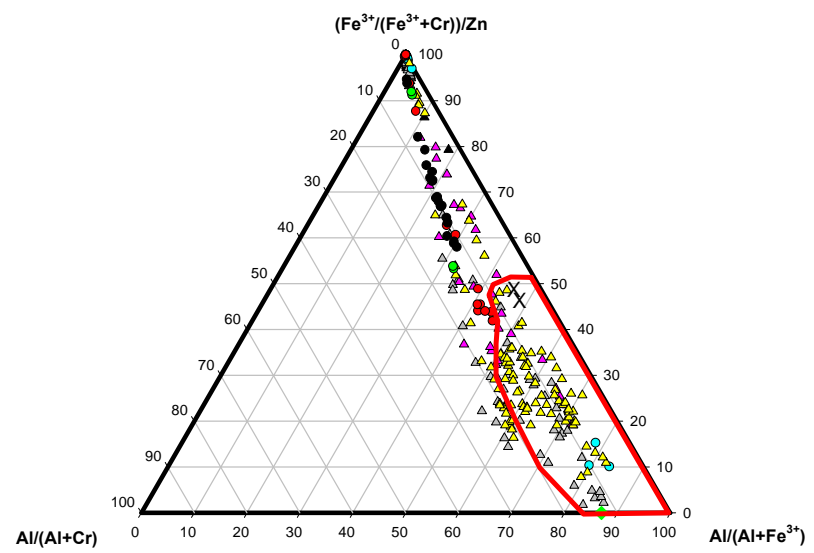
within lower right portion of the diagram (red outline). $\mathrm{X}$ are Zn-chromite of Meyer and Boyd (1972), green polygon average Brazilian Zn-chromite (Tappert, pers comm) Other symbols same as Figure 2

The evolutionary trends demonstrated for diamond affinity Zn-chromites are consistent with a magmatic origin and the elevated zinc contents are not considered to be the result of later mestasomatic or metamorphic activity. Regardless, the relative oxidation state (as reflected in the spinel ferric iron content) was sufficiently reducing in nature to allow diamond preservation.

\section{REFERENCES}

Meyer, H.O.A., Boyd, F.R. 1972. Composition and origin of crystalline inclusions in natural diamonds. Geochemica Cosmochimica Acta, 36, 1255-1273.

Sage, R. 2000. "Sandor" Diamond Occurrence. Michipicoten Greenstone belt, Wawa Ontario. Ontario Geological Survey Open File Report 6016.

Tappert, R., Stachel, T., Harris, J.W., Brey, G.P. 2002. Composition of mineral inclusions from Brazilian diamonds. GAC-MAC abstract volume, Saskatoon 2002. Pg 116

Weiser, T.W., Hirdes, W. 1997. Zince-rich chromite from Paleoproterozoic conglomerates at Tarkwa Gold Mine, Ghana. Canadian Mineralogist, 35, 587-595.

Contact: R.L. Barnett 9684 Longwoods Rd, London ON, N6P 1P2.rbarnett@odyssey.on.ca 